\title{
Evolution of thoracic surgery in Canada
}

\author{
Jean Deslauriers MD FRCSC ${ }^{1}$, F Griffith Pearson MD FRCSC ${ }^{2}$, Bill Nelems MD FRCSC ${ }^{3}$
}

J Deslauriers, FG Pearson, B Nelems. Evolution of thoracic surgery in Canada. Can Respir J 2015;22(2):e8-e14.

BACKGROUND: Canada's contributions toward the 21st century's practice of thoracic surgery have been both unique and multilayered. Scattered throughout are tales of pioneers where none had gone before, where opportunities were greeted by creativity and where iconic figures followed one another.

OBJECTIVE: To describe the numerous and important achievements of Canadian thoracic surgeons in the areas of surgery for pulmonary tuberculosis, thoracic oncology, airway surgery and lung transplantation.

METHOD: Information was collected through reading of the numerous publications written by Canadian thoracic surgeons over the past 100 years, interviews with interested people from all thoracic surgery divisions across Canada and review of pertinent material form the archives of several Canadian hospitals and universities.

RESULTS: Many of the developments occurred by chance. It was the early and specific focus on thoracic surgery, to the exclusion of cardiac and general surgery, that distinguishes the Canadian experience, a model that is now emerging everywhere. From lung transplantation in chimera twin calves to ex vivo organ preservation, from the removal of airways to tissue regeneration, and from intensive care research to complex science, Canadians have excelled in their commitment to research. Over the years, the influence of Canadian thoracic surgery on international practice has been significant. CONCLUSIONS: Canada spearheaded the development of thoracic surgery over the past 100 years to a greater degree than any other country. From research to education, from national infrastructures to the regionalization of local practices, it happened in Canada.

Key Words: Evolution; History; Thoracic surgery in Canada

\section{Evolution de la chirurgie thoracique au Canada}

HISTORIQUE : Les contributions canadiennes à la pratique de la chirurgie thoracique du 21e siècle sont uniques et multi-facettaires. A travers ces contributions, on retrouve des chirurgiens légendaires qui ont foulé des territoires jamais explorés antérieurement et où les opportunités ont été rencontrées avec créativité.

OBJECTIF : Rapporter les nombreuses et importantes réalisations de chirurgiens thoraciques canadiens dans les domaines de la chirurgie pour tuberculose pulmonaire, oncologie thoracique, chirurgie des voies aériennes et transplantation pulmonaire.

MÉTHODES : Lecture des nombreuses publications écrites par les chirurgiens thoraciques canadiens au cours des cent dernières années, entrevues avec personnes intéressées dans toutes les divisions de chirurgie thoracique pancanadiennes et révision de matériel pertinent en provenance d'archives de centres hospitaliers et universités canadiennes.

RÉSULTATS : Plusieurs développements importants sont survenus par chance ou par accident. En particulier, le focus spécifique sur la chirurgie thoracique, à l'exclusion de la chirurgie cardiaque et générale, est devenu un modèle reconnu et suivi partout au niveau mondial. De la transplantation pulmonaire chez des veaux identiques (chimera twin calves) à la préservation pulmonaire par perfusion ex-vivo, de la chirurgie des voies aériennes à la régénération tissulaire, de la recherche en soins intensifs à la science des complexités (complexity science), les chirurgiens thoraciques canadiens ont toujours considéré la recherche comme prioritaire. Au cours des années, l'influence de la chirurgie thoracique canadienne sur les pratiques internationales a été importante.

CONCLUSION : Le Canada a stimulé le développement de la chirurgie thoracique au cours des cents dernières années comme aucun autre pays. De la recherche à l'éducation, de la création d'infrastructures nationales à la régionalisation des pratiques locales, le système canadien et l'école de pensée canadienne sont maintenant reconnus au niveau planétaire.

world) in 1965 and 18 years later, Joel D Cooper performed the first successful human lung transplantation in the world. The development of ex vivo lung perfusion to assess, diagnose and treat injured donor lungs for successful transplantation was the result of extensive research work performed by Shaf Keshavjee and the Toronto Lung Transplant Group.

The early recognition of thoracic surgery in the fellowship program of the Royal College of Physicians and Surgeons of Canada (RCPSC) in 1946 and the recognition of thoracic surgery as a primary specialty to the exclusion of cardiac and general surgery in 1994 are all important milestones in the evolution of training and credentialing in the specialty.

The legacy of Canadian thoracic surgery around the world began in the earlier part of the 20th century with the influence of Norman Bethune in China. In 1935, Edward Archibald's presidential address to the American Surgical Association (1) also led directly to the recognition of the first American Board of Surgery and system of certification by examination, which began in the United States in 1937.

\section{HISTORY OF SURGERY FOR PULMONARY TUBERCULOSIS IN CANADA}

Pulmonary tuberculosis, often called 'phthisis' or the 'Great White Plague' was the disease that initiated the birth of thoracic surgery near the end of the 19th century. It was one of the few remaining unsolved epidemics, its incidence having been accelerated by the industrial revolution all over Europe with population shifts toward the cities,
Following experimental work on chimera twin calves, Darrell D Munro performed the first Canadian lung transplantation (fifth in the

\footnotetext{
${ }^{1}$ Institut Universitaire de Cardiologie et de Pneumologie de Québec, Quebec City, Quebec; ${ }^{2}$ Toronto General Hospital, Toronto, Ontario;

${ }^{3}$ Kelowna General Hospital, Kelowna, British Columbia

Correspondence: Dr Jean Deslauriers, Institut Universitaire de Cardiologie et de Pneumologie de Québec, 2725 chemin Ste-Foy, Quebec City,

Quebec G1V 4G5. Telephone 418-656-8711 ext 5504, fax 418-656-4762, e-mail jean.deslauriers@chg.ulaval.ca
} 


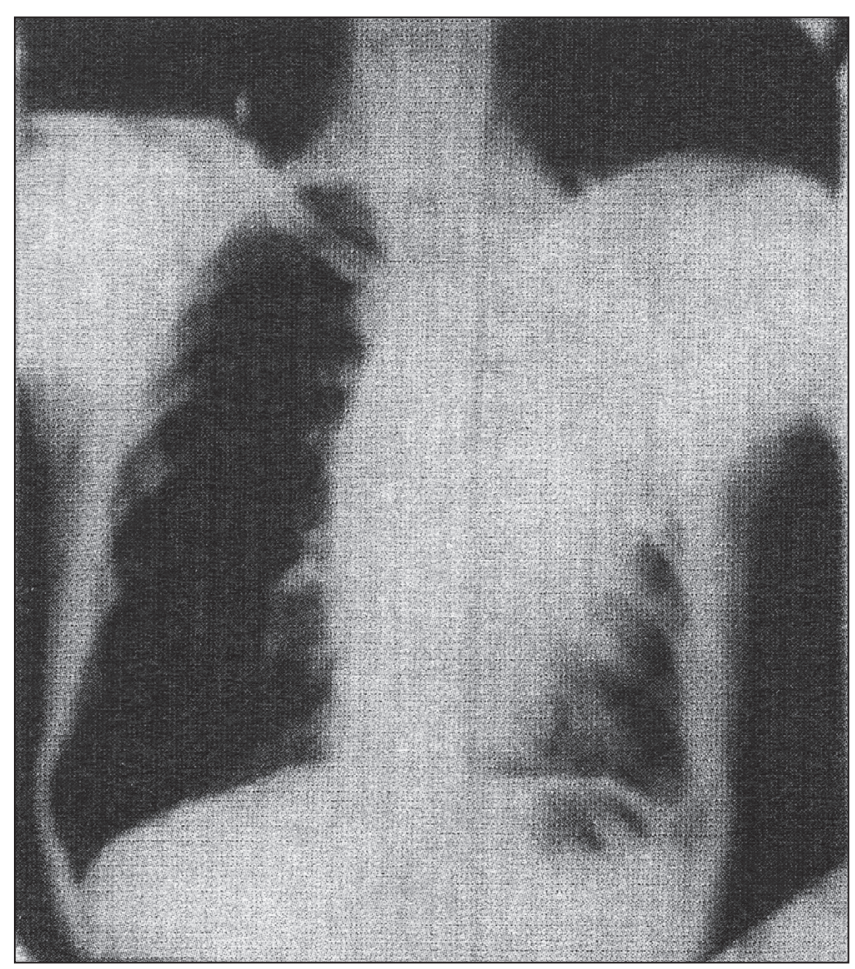

Figure 1) Posteroanterior chest radiograph of Norman Bethune on arrival at the Trudeau Sanatorium (Saranac Lake, New York, USA) in December 1926, showing severe tuberculous pneumonia in the left upper lobe

overcrowding, and people living in generally poor hygienic conditions. At the time, it was considered to be the most common cause of death worldwide. Canadian mortality figures in relation to tuberculosis were significant and, in 1901, for instance, there were almost 10,000 deaths from this disease $(180$ per 100,000$)$ in Canada (2).

Sanatoriums, where the objective was to control the disease through isolation, bed and lung rest in fresh open air, and good nutrition, were then opened everywhere and contributed to some improvement in mortality.

Surgical procedures designed to create partial or complete collapse of the more diseased portions of the lung became popular during the last part of the 19th century. The speculation was that putting the lung at rest would allow diseased tissues to be replaced by fibrous tissues (3). Another potential benefit of collapse therapies was to lessen the size of tuberculous cavities.

Artificial pneumothorax, which had been initiated in 1882 by an Italian physician, Carlo Forlanini (4), became very popular and sputum could be converted in nearly $90 \%$ of patients. At the highest peak of its popularity in the 1930s, it was attempted in $60 \%$ of all admissions at the Weston Sanatorium near Toronto (Ontario) and, in 1943, approximately 12,000 patients had an established pneumothorax that needed to be 'refilled' as in- or outpatients (2).

When Norman Bethune entered the Trudeau Sanatorium (Lake Saranac, New York, USA) in December 1926, he was severely ill with left upper lobe tuberculous pneumonia (Figure 1). After much discussion, an artificial pneumothorax was induced on Bethune's left lung and, within two months, his sputum had turned negative. For several years thereafter, Bethune continued to undergo pneumothorax refills, and his tuberculosis never recurred despite the extreme physical conditions of deprivation of food and rest on the battlefields of China.

Because pleural adhesions would often prevent the success of artificial pneumothoraces, it became obvious that some other procedure would be needed to predictably achieve lung collapse. This led to the development of the operation of thoracoplasty, which, in simple terms, involved rib resection so that the chest wall would sink in and permanently collapse the lung. By 1921, Edward W Archibald from McGill University

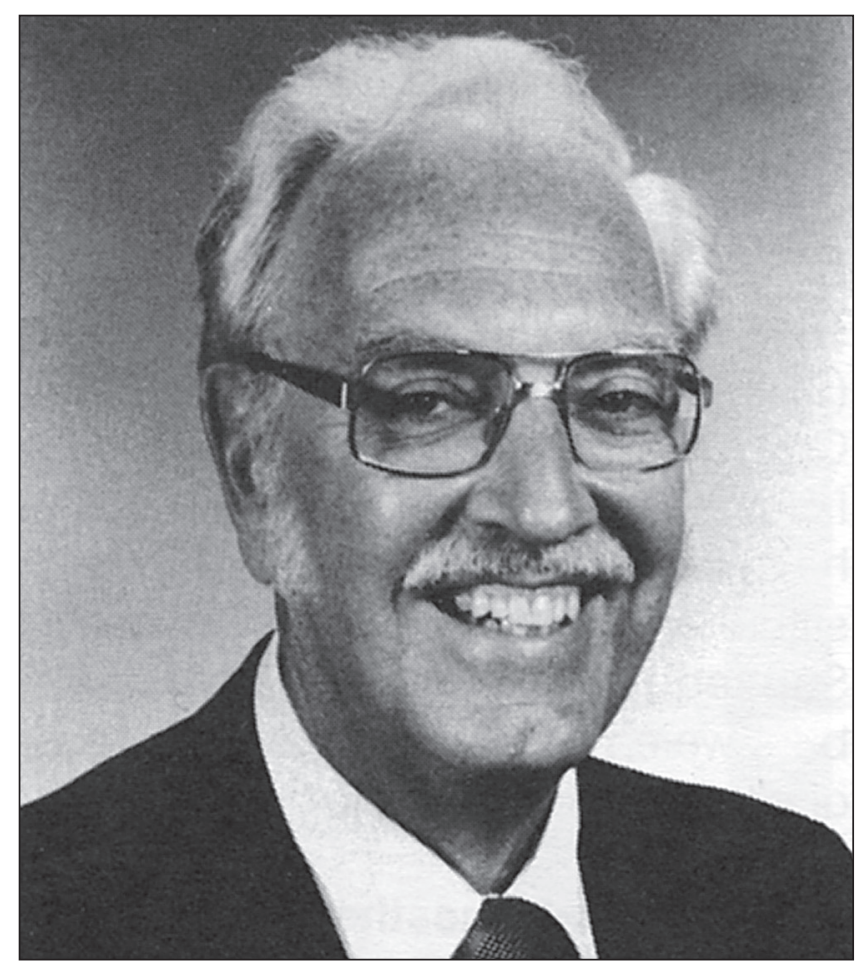

Figure 2) Norman C Delarue, whose efforts to control cigarette smoking have been widely recognized

(Montreal, Quebec) was acknowledged as the world leader in the field and the procedure he used was named 'extrapleural thoracoplasty'. In an article published in the Canadian Medical Association Journal in 1921, Archibald wrote the following about thoracoplasty (3):

Not only is the lung and its contained cavities compressed but it is also prevented from going on with its physiological work; it rests. Nature's efforts at repair are therefore unhindered. She gradually replaces diseased tissues with fibrous tissues; healing advances through scar.

Some of today's thoracic surgeons and, for that matter, anesthesiologists and chest physicians, would be surprised to learn that many thoracoplasties were performed under spinal anesthesia so that the patient could cough and expectorate during the operation, thus preventing the much feared contralateral spread of disease. In Montreal, for instance, Fraser B Gurd became a strong proponent of this approach because he believed that the postoperative course was much less stormy and that contralateral spread of disease had almost ceased to be a problem (5). Thoracoplasty for the treatment of tuberculosis was largely abandoned in the 1950s.

The first elective pulmonary resection (lobectomy) for tuberculosis in Canada was performed in 1936 by Norman S Shenstone at the Toronto Weston Sanatorium. By 1947, several large series of resection of tuberculous lung had been reported with operative mortality rates ranging from $6 \%$ to $35 \%$. One such series was that of Robert M Janes of Toronto (6), who summarized his thoughts in the following terms:

A survey of the results obtained by pulmonary lobectomy by the dissection technique in this small group of patients would suggest that the procedure is a satisfactory one if proper indication exists. The cases with persistent cavities could not have been controlled with certainly with any other method.

By the late 1950s, the number of resections had declined significantly because antituberculous drug therapy had become effective. Surgical salvage procedures including resections, thoracoplasties and decortications were, however, still performed when medical therapy has failed. According to legend, it is estimated that Darrell Munro and James Wilson, from the 


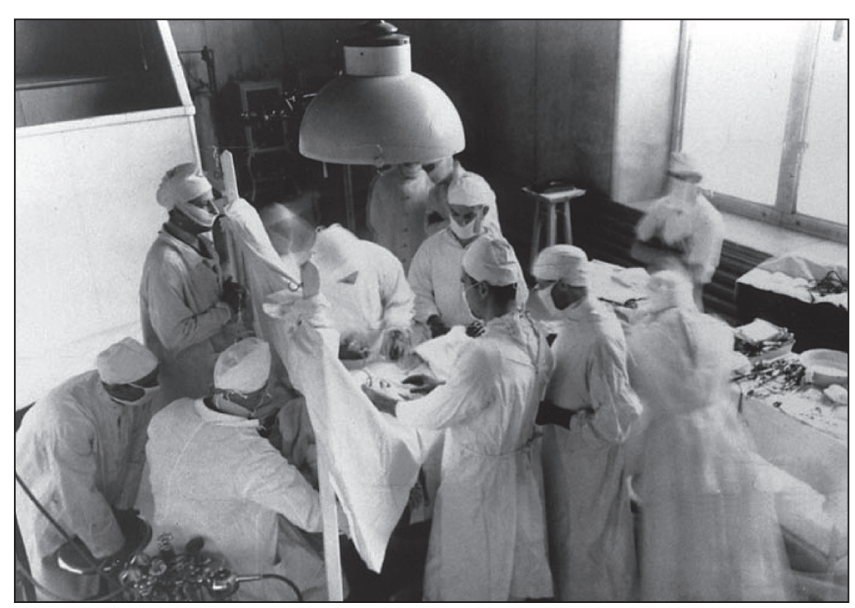

Figure 3) First successful pneumonectomy with individual ligation of hilar structures performed in Montreal on July 7, 1933. The operating surgeon is Edward Archibald, who is to the left of the patient and bent over. His assistants are Norman Bethune, who is facing Archibald, and Arthur Vineberg, who is standing beside Bethune (courtesy of Lloyd D MacLean)

Royal Edward Chest Hospital in Montreal, performed approximately 1000 such operations for tuberculosis with only eight postoperative deaths, three of which being "in patients who killed themselves because the disease was not or could not have been completely resected".

\section{THE EPIDEMIC OF LUNG CANCER THAT BEGAN IN THE 1950s}

In the early 1950s, primary lung cancer was rarely encountered in women and adenocarcinomas were extremely uncommon. Nothing definite was known regarding the cause of disease. In 1951, Robert M Janes wrote the following about the etiology of lung cancer (7):

It has been attributed to the use of tar in road building but Boyd showed that it seemed to be more frequent in Winnipeg than in Toronto. It has been blamed upon the inhalation of petrol fumes but seems to be as common in rural as well as urban communities. The belief that it is due to tobacco does not seem to be well-founded.

In the 1960s, preoperative evaluation was primitive and the work-up essentially consisted of a clinical history, standard $\mathrm{x}$-rays, rigid bronchoscopy and exploratory thoracotomy. Scalene node biopsy was sometimes used to document lymphatic spread. A simplified 'stair test' to assess pulmonary function was used. If the patient could climb one flight of stairs without stopping, one could take out a lobe, but if he could climb two flights, one could take out the whole lung. As many as $40 \%$ of presumed operable lung cancers were found to be unresectable at thoracotomy and the operative mortality for pulmonary resection ranged between $10 \%$ and $20 \%$.

The past 50 years have witnessed significant improvements in the understanding of the cause of disease, selection for surgery, types of operations and the role of adjuvant therapies. In all of these developments, Canadian thoracic surgeons have played prominent roles.

When he was a fellow with Evarts Graham in St Louis (Missouri, USA) after World War II, Norman C Delarue from Toronto (Figure 2) developed a keen interest in the association between smoking and lung cancer and was one of the first - if not the first - to produce a statistically valid analysis implicating cigarette smoking in the pathogenesis of lung cancer (8). This effort led to a life-long antismoking crusade and, in his honour, Physicians for a Smoke-Free Canada created the 'Norman Delarue Award', which is given to deserving individuals for their outstanding work in tobacco control.

Mediastinoscopy was introduced in North America and popularized around the world by Griff Pearson in the early 1960s (9) and the routine use of this technique helped reduce the incidence of fruitless

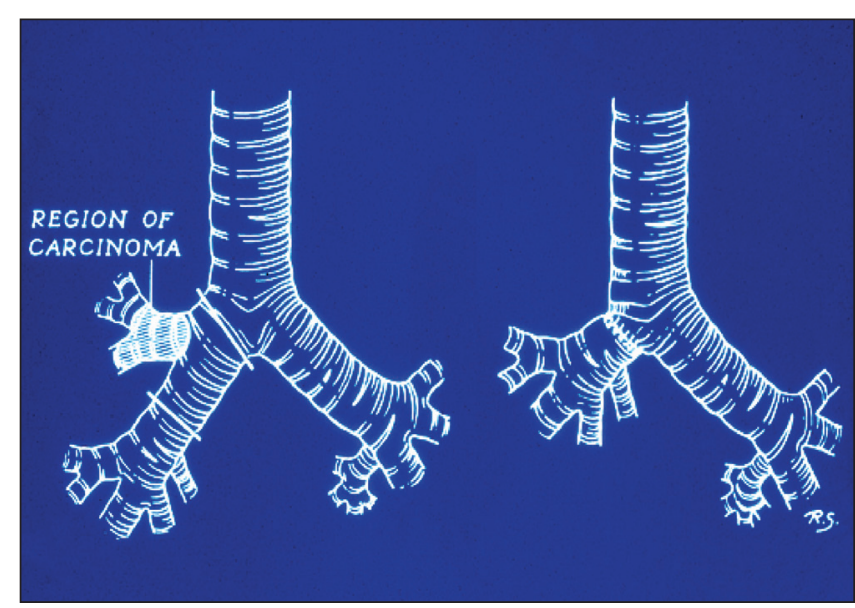

Figure 4) Original diagram from FG Pearson illustrating the operation of right upper lobe sleeve resection. Courtesy of FG Pearson

thoracotomies to $<5 \%$. Kazuhiro Yasufuku, whose professional career had begun at Chiba University in Japan but who was recruited in Toronto in 2008, helped develop a new convex probe permitting realtime endobronchial ultrasonography with guided transbronchial needle biopsy. In a landmark study (10), Yasufuku et al showed no significant differences between endobronchial ultrasonography-transbronchial needle aspiration and mediastinoscopy in determining the true pathological mediastinal lymph node stage.

On April 5, 1933, Evarts Graham, a reputed thoracic surgeon from St Louis (Missouri, USA), performed the first successful one-stage pneumonectomy (left) for lung cancer using the mass ligation technique (11). Three months later, on July 7, 1933, Edward Archibald performed the first successful pneumonectomy (left) (Figure 3) with individual ligation of hilar structures at the Royal Victoria Hospital in Montreal (12). His technique was essentially the same as that which is used today and, accordingly, he is considered to be one of the fathers of modern pneumonectomy (13). Despite significant operative mortality rates (20\% to $50 \%)$, pneumonectomy remained the procedure of choice for the surgical management of lung cancer until the early 1950s when Edward Churchill and Richard Sweet from the Massachusetts General Hospital (Boston, USA) suggested that lobectomy may be an adequate procedure (14). From that point on, lobectomy has been the operation of choice for the resection of lung cancer. In 1982, Robert J Ginsberg and the Lung Cancer Study Group initiated a randomized clinical trial comparing lobectomy with limited resection in patients with T1N0 lung cancer (15). There was a threefold increase in local recurrences in the limited resection group and a survival advantage, although nonsignificant, to lobectomy. Based on this information, Ginsberg and the Lung Cancer Study Group concluded with the following remark (15): "Lobectomy must still be considered the procedure of choice for patients with peripheral T1NO non-small cell lung cancer."

Sleeve lobectomy (Figure 4) is a lung-saving operation usually indicated for centrally located lung cancer. The first such procedure was performed in 1947 by Sir Clement Price Thomas of London, United Kingdom (16) and, in Canada, the first case was performed in February 1952 in Quebec City by Joffre-André Gravel (17), one of the founding members of the Society for Thoracic Surgeons. Such procedures are no longer restricted to patients with compromised lung function and both Jean Deslauriers (18) and Griff Pearson have helped popularized these operations worldwide.

Perhaps the most celebrated study in the history of Canadian thoracic oncology was the BR10 National Cancer Institute of Canadasupported randomized trial, which was undertaken to determine whether adjuvant vinorelbin plus cisplatin prolongs survival among patients with completely resected early-stage non-small-cell lung cancer. With Timothy Winton from Toronto as principal investigator, the 


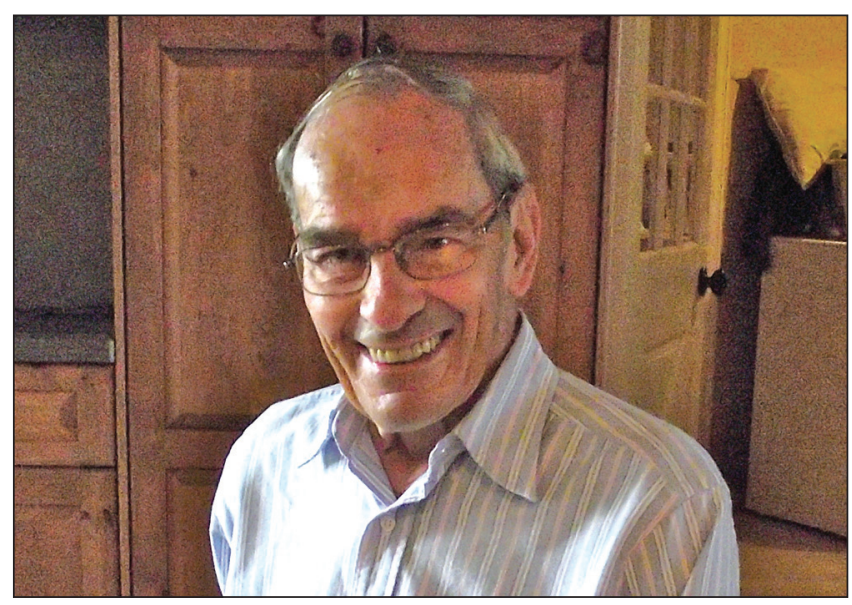

Figure 5) Frederick Griffith ('Griff') Pearson, 'Lord of the tracheal rings'. Photograph taken in 2011

study was the first ever to demonstrate a significant benefit in terms of prolonged disease-free survival and overall survival in patients receiving adjuvant chemotherapy (19).

\section{BIRTH OF AIRWAY SURGERY}

Significant developments in airway surgery largely occurred following the introduction of mechanical ventilation and intubation with cuffed translaryngeal and tracheostomy tubes in the 1950s. At the time, tracheostomy tubes were thick walled and rigid, and the cuffs were round and firm. Numerous factors were believed to be associated with the plethora of postintubation tracheal injuries that followed the use of those tubes and, in 1968, Griff Pearson and Melvin Goldberg were the first to make the observation that high ventilator pressures and, therefore, high pressure between cuff and tracheal wall, was likely the most important pathogenetic factor in the development of benign tracheal strictures (20). In that seminal paper, Pearson et al wrote the following:

In seven patients, stenosis developed in the mediastinal trachea at the level of the inflatable cuff. In each patient, the lesion was identified as a firm, concentric, fibrous stenosis. It is assumed that pressure between the cuff and the tracheal wall led to circumferential mucosal ulceration and injury to underlying connective tissue and cartilage with subsequent healing by concentric scar contracture.

To better evaluate the incidence of tracheal injuries following tracheostomy with a cuffed tube, a prospective study was then initiated in January 1967 for all patients entering the Respiratory Failure Unit at Toronto General Hospital (TGH, Toronto, Ontario) and requiring tracheostomy with a cuffed tube. It was concluded that prevention of tracheal injuries could be possible, to a high degree, through the use of large-volume and low-pressure (floppy) cuffs (21). In an experiment performed on dogs in the early 1970s at the Banting Institute in Toronto, the same authors were also the first to show that greater degrees of tracheal injury occurred with cuffed than with uncuffed tubes, and still greater injury was observed in animals in which high inflation pressures had been used (22).

In 1960, it was generally accepted that surgeons could safely remove no more than two or three tracheal rings - the ' $2 \mathrm{~cm}$ rule' and predictably be able to reconstruct the airway with primary anastomosis. It was believed that tracheal cartilages healed poorly, and it was also believed that anesthesia could be difficult to maintain during reconstruction. By the late 1960s, however, the $2 \mathrm{~cm}$ rule was being challenged due to improved knowledge of airway anatomy and blood supply, use of tension-releasing manoeuvres and better anesthetic techniques. In the adult patient, for instance, approximately one-half of the tracheal length can now be circumferentially removed and

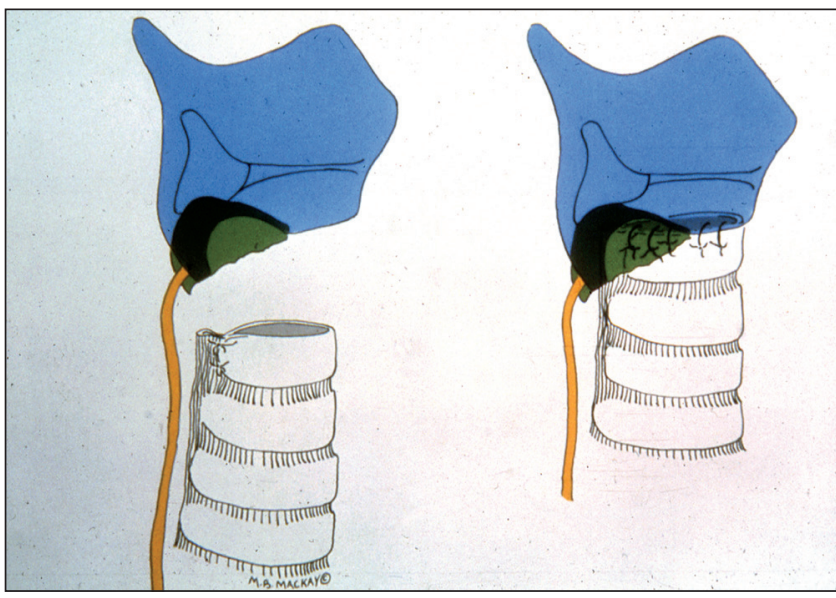

Figure 6) The 'Pearson operation' for subglottic strictures. Courtesy of FG Pearson

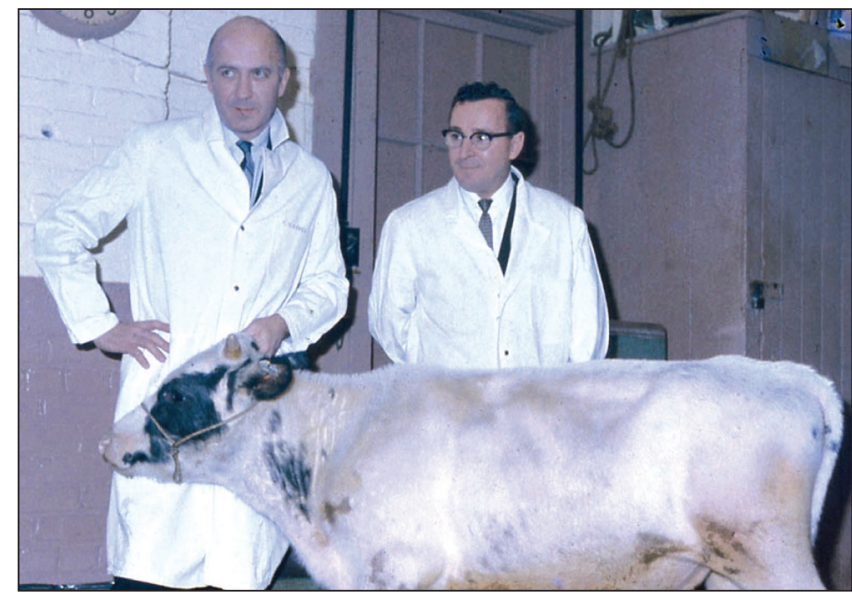

Figure 7) Darrell Munro (on the left) with a transplanted chimera twin calf

continuity restored by primary end-to-end anastomosis. The most prominent contributors in the field were Hermes C Grillo of Boston (Massachusetts, USA), who unfortunately died in a road traffic accident in 2006, and Griff Pearson of Toronto (Figure 5).

When stenotic lesions involve the airway at the cricoid level, surgery becomes more complex because complete transection of the airway inevitably results in the division of both recurrent laryngeal nerves. In 1975, Griff Pearson and colleagues from Toronto reported on six patients with subglottic stenotic strictures involving the cricoid who had been successfully treated by segmental resection and removal of all but a thin shell of posterior cricoid lamina, allowing for preservation of the recurrent laryngeal nerves (Figure 6) (23). The operation - now called the 'Pearson operation' - is one of the most significant contributions to airway surgery worldwide.

\section{LUNG TRANSPLANTATION}

The story of lung transplantation is extraordinary and one of the most significant in all Canadian medical history. It began in the early 1960s when Darrell Munro performed experimental lung transplantations on chimera twin calves (Figure 7). These calves were absolutely identical because they shared the same placenta. They were, thus, fully compatible and tissue exchange could be accomplished without any rejection phenomena. Interestingly, all of this experimental work was performed at the École de Médecine Vétérinaire de St-Hyacinthe (Eastern township, Quebec) with the help of a surgical resident and a veterinarian. The Montreal Chest Hospital provided all instruments and supplies as well as personnel, including double scrub teams, nurses and anesthesiologists (eight to 10 individuals). The operating room was in a barn adjacent to the school, and they used bales of straw for operating 


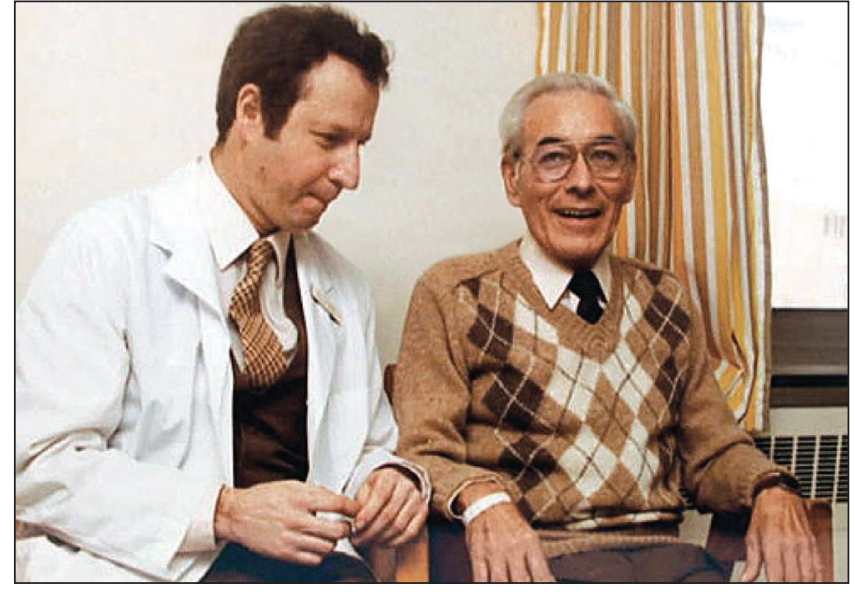

Figure 8) A pensive Joel Cooper supports a smiling Tom Hall

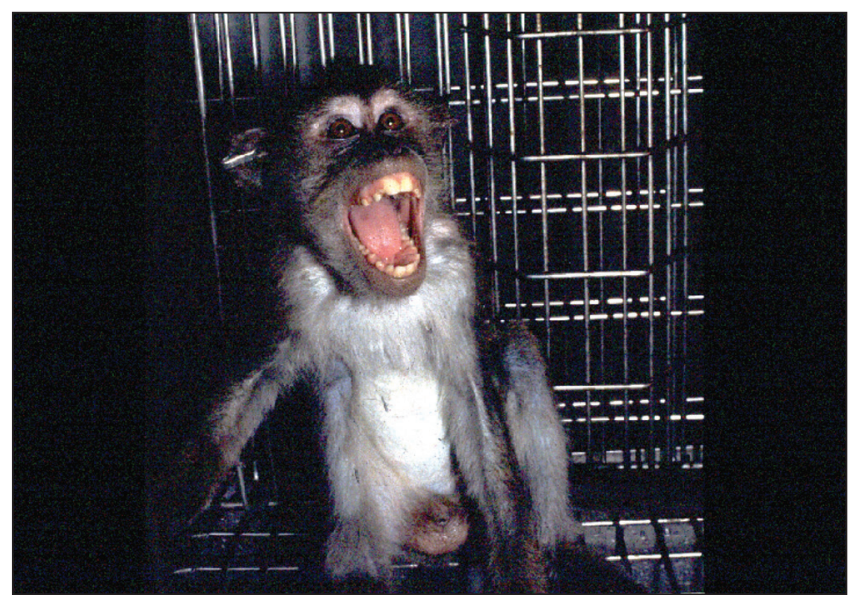

Figure 9) Photograph of a cynomolgus monkey named Hercules. He was a mean, determined animal and was the first long-term survivor of the en bloc double lung transplant procedure. When he died after three months, the tracheal anastomosis was perfectly healed. Courtesy of John Dark, United Kingdom

tables. On September 29, 1965, Darrell Munro also performed the first human lung transplantation in Canada at the Royal Victoria Hospital in Montreal (24). The recipient was a 31-year-old man with end-stage respiratory failure due to silicosis. In a twist of luck, the donor, who had been involved in a motor vehicle accident, was himself on a waiting list for renal transplantation. When interviewed before his death by one of the authors of the present article (JD), Dag Munro said the following:

Because the donor was on a waiting list for kidney transplant, his wife was easily convinced to donate her husband's lung for transplantation.

The patient died one week postoperatively due to anastomotic dehiscence. Munro cited the recipient's lung disease as being too far progressed and the donor's lung as possibly having been infected as factors that led to the patient's death (24).

The most important gains in lung transplantation, however, would come later from Toronto and research would become the driver for success. In 1977, Bill Nelems performed Canada's second lung transplantation at Toronto General Hospital (25) - the 38th case in the world at that time. That patient would also die of a bronchial anastomotic dehiscence, which occurred on postoperative day 19 as a consequence of heavy dosages of cortisone used to prevent rejection.

Early on the morning of November 7, 1983, a team of Toronto General Hospital surgeons, led by Joel Cooper, began a lung transplantation that would make medical history (26). The patient was

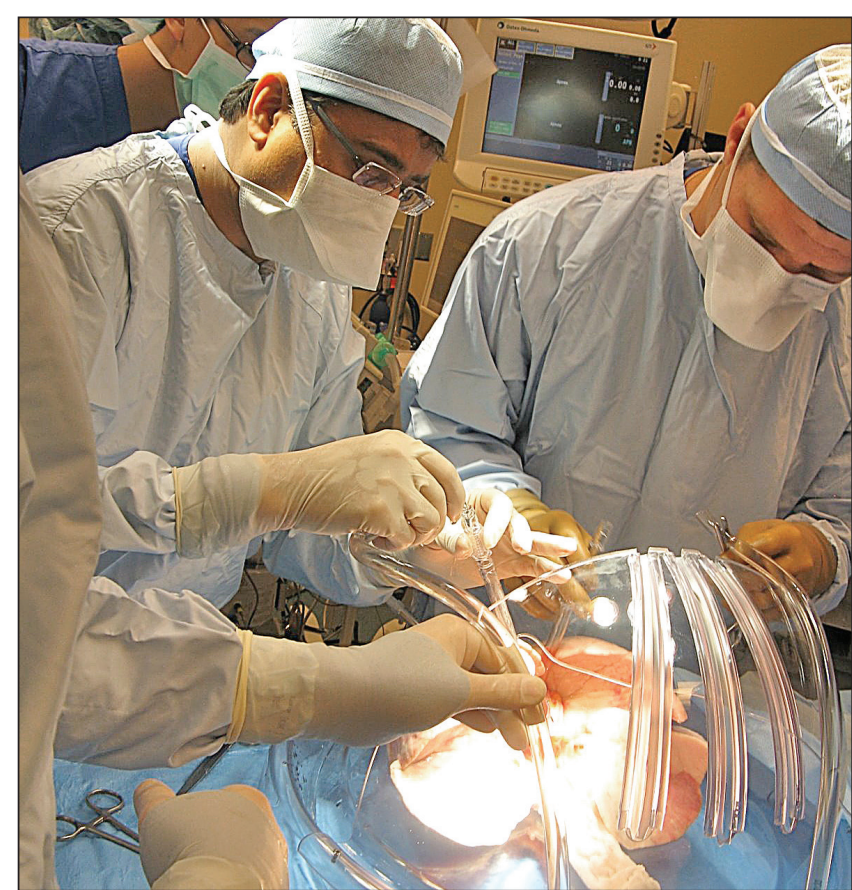

Figure 10) Shaf Keshavjee (left) and Marcelo Cypel preparing an ex vivo specimen in 2012

Tom Hall (Figure 8), the 45th patient in the world to undergo this risky procedure but the first to become a long-time survivor. This is a Canadian success story - a story of courage, innovation, passion, perseverance and team work. From the performance of this first successful single lung transplantation, many of the other major innovations in the field have emanated from the Toronto Lung Transplant Program. These milestones include the first successful double-lung transplantation in the world in 1986 (Figure 9) (27) by GA Patterson, the first successful bilateral lung transplantation for cystic fibrosis in the world (1988) and the invention of low potassium dextran (LPD) lung preservation solution, which made safe and reliable lung preservation a clinical reality (28). This innovation went on to be commercialized as Perfadex (Xvivo Perfusion AB, Sweden), which has since become the worldwide standard for clinical lung preservation.

In 2000, the Toronto Extracorporeal Lung Support Program was formalized and has grown from a handful of cases per year to $>40$ cases per year using advanced artificial lung technologies. Patients are supported with artificial lung devices as a bridge to lung transplantation (29), as a bridge to recovery after lung transplantation if needed, and to treat acute respiratory failure in severe adult respiratory distress syndrome.

The development of extended ex vivo lung perfusion by Shaf Keshavjee and Marcelo Cypel (Figure 10) to assess, diagnose and treat injured donor lungs for successful transplantation was the result of an extensive laboratory research project to develop strategies to repair the donor lung to improve outcomes after transplantation. This innovative strategy was tested in a successful clinical trial (30) and, according to Shaf Kesjhavjee, it has transformed the field of lung transplantation and promises to have a similar effect on the entire field of transplantation of all organs. It has opened the door to the potential for 'personalized medicine for the organ'.

In 2011, the world's first clinical organ repair laboratory was opened in the TGH operating rooms, where lungs are repaired not only for the TGH program but also for other programs. Lungs are able to be brought in, repaired and transported to another centre for transplantation.

\section{EMERGENCE OF THORACIC SURGERY AS A SPECIALTY}

Most of the surgery performed through the 1940s and 1950s was focused on pleural and pulmonary sepsis, including the surgery of 
tuberculosis. All surgeons involved in this work had begun as general surgeons but had become increasingly occupied with thoracic surgery. In 1942, the RCPSC established a certification in the subspecialty of thoracic surgery. When this certification was discontinued in 1964 to be replaced by a combined fellowship in cardiovascular and thoracic (CVT) surgery, 68 surgeons, most working primarily in sanatoriums, had been granted certification in the specialty.

In 1970, Griff Pearson sent a memorandum to the RCPSC requesting revisions of the training program in CVT surgery and requirements for certification in noncardiac thoracic surgery. In his memorandum, Pearson wrote the following:

It is increasingly evident to many Canadian surgeons that the present training programmes and criteria for certification in thoracic surgery are unsatisfactory. This memorandum is intended to define inadequacies which exist presently and suggest modifications in both training requirements and method of certification, in order to produce graduates who are better qualified to provide healthcare requirements in this area today.

The specialty is "regionally rather than system orientated" wrote Griff Pearson, and it includes the surgery of the tracheobronchial tree and lungs, mediastinum, chest wall and esophagus. He also noted that, due to the significant increase in lung cancer and chest trauma, the present volume of surgery was larger than ever. He believed that in the combined thoracic and cardiovascular units, the thoracic work was often treated 'casually' with the emphasis being on open heart surgery.

At the CVT specialty committee meeting held in Ottawa (Ontario) on June 28, 1971, the committee was in general agreement with Pearson and stated:

It is unanimously agreed that the cardiovascular units across Canada are unable to service the entire needs in general thoracic surgery, and that modifications in training requirements and special certification in general thoracic surgery would be desirable to upgrade the quality of general thoracic surgery.

As a result of this recommendation and based on the results of the survey that followed, the RCPSC approved a certificate of special competence in 1978, and thoracic surgery was officially recognized as a specialty in 1994. This initiative of Griff Pearson has now been followed throughout the world. In his 1989 book on Thoracic Surgery in Canada (31), Norman C Delarue wrote the following:

General Thoracic Surgery already has a glorious past. Its present status as a recognized specialty honours the surgical pioneers who made this recognition inevitable.

\section{LEGACY OF CANADIAN THORACIC SURGERY WORLDWIDE}

The legacy of Canadian thoracic surgery around the world began in the earlier part of the 20th century with the influences of Norman Bethune in the People's Republic of China and of Edward Archibald in the United States. While in China (1938 to 1939), Bethune created a school of medicine in Changchun, Jilin Province, and wrote textbooks (Figure 11) that were later translated into Chinese. Recognizing that his Chinese colleagues were completely untrained but dedicated, intelligent, anxious to save and aspiring to be of aid to suffering humankind, he gave them daily courses on basic anatomy, physiology and how to treat minor wounds. He understood that more doctors and nurses were needed, and he took young peasants, whom he called 'barefoot doctors' (docteurs aux pieds nus) and graduated them in one year for doctors and six months for nurses. Mostly because of his work in China, where he remains to this day the only foreigner to ever become a national hero in that country, Alexander Walt credited Bethune as being the world's best known surgeon (32).

One of the important - if not the most important - contributions of Edward Archibald was his emphasis on education in surgery. He

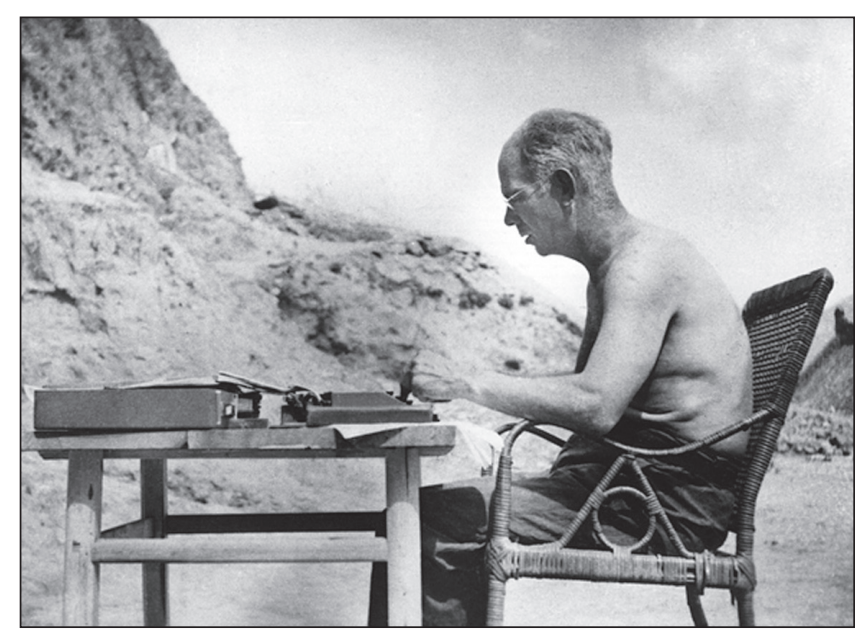

Figure 11) Photograph of Norman Bethune writing a medical textbook during his time in China

believed that students should understand the fundamentals of physiological and anatomical disorders for which surgery was the therapeutic approach. His presidential address at the 1935 meeting of the American Surgical Association (1) led directly to the appointment of the first American Board of Surgery and the process did much to stimulate better training. He became recognized as one of North America's premier teachers and in his obituary note, Evarts Graham said the following about Archibald (33):

The recognition by the US Army and Navy of the value of certification by that board is doubtless responsible, in no measure, for the unexcelled record of accomplishment in the treatment of wounded soldiers and sailors, of World War II. This in itself constitutes a fitting memorial of the wisdom and foresight of Edward Archibald.

Soon after World War II, Norman Shenstone, Robert Janes and Frederick Kergin were part of the team primarily responsible for the recognition given to $\mathrm{TGH}$ as one of the most important centres in the development of thoracic surgery in the world. Indeed, the TGH division of thoracic surgery became a prototype for other similar units worldwide. Griff Pearson, a disciple of Frederick Kergin, followed in his footsteps and contributed extensively to the recognition of thoracic surgery. $\mathrm{He}$ conceived and developed original techniques in all aspects of the specialty and is widely acknowledged as a living legend. His efforts combined to those of Bob Ginsberg, a pioneer in thoracic oncology led to a major influx of trainees from all over the world in Toronto. On returning to their countries, most of these trainees were able to develop successful programs of their own.

Exploration of the role of lung transplantation proceeded in gradual fashion through the work of Joel Cooper, Alec Patterson and Shaf Keshavjee. The Toronto Lung Transplant Program is now acknowledged as one of the best in the world and fellows from everywhere come to learn in the Latner Thoracic Surgery Research Laboratory in Toronto. Again, many of these trainees have gone back to their own countries and have started successful lung transplant programs.

As is clear, the "Canadian School of thought" is now recognized internationally for consistently applying the concepts of sharing ideas, teaching operative techniques and training young surgeons. It has had a major influence on the development of parts or of the whole specialty in several countries on all continents.

\section{CONCLUSION}

Canada spearheaded the development of thoracic surgery over the past 100 years to a greater degree than any other country. From research to education, from national infrastructures to local practice, it happened in Canada. Looking back is a respectful pursuit; it pays tribute to our 
heritage and to our pioneers, and it gives us insights into our genetic coding - who we are and how we evolved. Looking back teaches us lessons we could learn in no other way, and it prevents us from making the same mistakes twice.

DISCLOSURES: The authors have no financial disclosures or conflicts of interest to declare.

CANADIAN THORACIC SURGEONS MENTIONED IN THE TEXT AND WHERE THEY WORK(ED): Edward William Archibald (1872-1945), McGill University, Montreal, Quebec; Henry Norman Bethune (1890-1939), McGill University, Montreal, Quebec; Joel D Cooper (1939- ), University of Toronto, Toronto, Ontario (currently practising in Philadelphia); Marcelo Cypel (1976- ), University of Toronto, Toronto, Ontario; Norman C Delarue (1915- exact year of death unknown), University of Toronto, Toronto, Ontario; Jean Deslauriers (1945- ), Laval University, Quebec City, Quebec; Robert J Ginsberg (1940-2003), University of Toronto, Toronto, Ontario; Melvin Goldberg (1941- ), University of Toronto, Toronto, Ontario; Joffre-André Gravel (1915-exact year of death unknown), Laval University, Quebec City, Quebec; Fraser B Gurd (1883-1996), McGill University, Montreal, Quebec; Robert M Janes (1894-1966), University of Toronto, Toronto, Ontario Frederick Kergin (1907-1974), University of Toronto, Toronto Ontario; Shaf Keshavjee (1961- ), University of Toronto, Toronto, Ontario; Darrell Dag Munro (1909-2012), McGill University, Montreal, Quebec; Bill Nelems (1939- ), University of Toronto, Toronto, Ontario (currently retired in Kelowna, British Columbia); G Alec Patterson (1949- ), University of Toronto, Toronto, Ontario (currently practising in St Louis, Missouri, USA); Frederick Griffith Pearson (1926- ), University of Toronto, Toronto, Ontario; Norman S Shenstone (1881-1970), University of Toronto, Toronto, Ontario; James Wilson (1923-1998), McGill University, Montreal, Quebec; Timothy Winton, University of Toronto, Toronto, Ontario (currently practising in Edmonton, Alberta); Kazuhiro Yasufuku (1965- ), University of Toronto, Toronto, Ontario.

\section{NOTE FROM THE EDITORS OF THE CANADIAN} RESPIRATORY JOURNAL: The authors of the present review, Jean Deslauriers, Bill Nelems and F Griffith Pearson, have recently published a book entitled Evolution of Thoracic Surgery in Canada (Decker Intellectual Properties, Hamilton, 2015). We believe that all readers of the Canadian Respiratory Journal should be interested by this book because they themselves have been part of this evolution. The book, which is both unique and spectacular, can be purchased through the Canadian Association of Thoracic Surgeons (CATS) at: http://canadianthoracicsurgeons.ca/evolution-of-thoracic-surgery-in-canada/. Of note, all proceeds from book sales are donated to a foundation to support research and education in Canadian thoracic surgery.

\section{REFERENCES}

1. Archibald EW. Address of the President. Higher degrees in the profession of surgery. Ann Surg 1935;102:481-95.

2. Gale GL, Delarue NC. History of Canadian surgery. Surgical history of pulmonary tuberculosis. The rise and fall of various technical procedures. Can J Surg 1969;12:381-8.

3. Archibald EW. Surgery in the treatment of pulmonary tuberculosis. Can Med Assoc J 1921;11:945-6.

4. Forlanini C. A Contribuzione Della Terapia Della Tisi. Abiazione Del Polmone? Pneumotrace Artificiale? Primo Case Di Tisi Pulmonare Monolaterale Avanzata Curato Felicemente Col Pneumotrace Artificiale Gaz Osp 1882;68:537-9.

5. Gurd FB, Vineberg AM, Bourne W. Further experience in the use of spinal anesthesia for thoracoplasty. Ann Surg 1939;110:872-7.

6. Janes RM. Total and partial pneumonectomy in the treatment of pulmonary tuberculosis. J Thorac Surg 1945;14:3-19.
7. Janes RM. What to know about carcinoma of the lung. Ariz Med 1951;8:36-8.

8. Collishaw N. History of tobacco control in Canada. Ottawa: Physicians for a Smoke-Free Canada; November 2008.

9. Pearson FG. Mediastinoscopy: A method of biopsy in the superior mediastinum. J Thorac Cardiovasc Surg 1965;49:11-21.

10. Yasufuku K, Pierre A, Darling G, et al. A prospective controlled trial of endobronchial ultrasound-guided transbronchial needle aspiration compared with mediastinoscopy for mediastinal node staging of lung cancer. J Thorac Cardiovasc Surg 2011;142:1393-400.

11. Graham EA, Singer JJ. Successful removal of an entire lung for carcinoma of the bronchus. J Am Med Assoc 1933;101:1371-4

12. Archibald $\mathrm{E}$. The technique of unilateral pneumonectomy. Ann Surg 1934;100:796-811.

13. White JJ, Archibald E, Rienhoff W Jr. Fathers of the modern pneumonectomy - a historical footnote. Surgery 1970;68:397-402.

14. Churchill ED, Sweet RH, Soutter L, et al. The surgical management of carcinoma of the lung. A study of the cases treated at the Massachusetts General Hospital from 1930 to 1950. J Thorac Surg 1950;20:349-63.

15. Lung Cancer Study Group. Randomized trial of lobectomy versus limited resection for T1N0 non-small cell lung cancer. Ann Thorac Surg 1995;60:615-23.

16. Price TC. Conservative resection of the bronchial tree. J R Coll Surg Edinb 1956;1:169-86.

17. Gravel JA. Bronchial resection and anastomosis: Report of a case. J Thorac Surg 1954;27:244-50.

18. Deslauriers J, Grégoire J, Jacques LF, et al. Sleeve lobectomy versus pneumonectomy for lung cancer: A comparative analysis of survival and sites of recurrences. Ann Thorac Surg 2004;77:1152-6.

19. Winton T, Livingston R, Johnson D, et al. Vinorelbine plus cisplatin vs observation in resected non-small cell lung cancer N Engl J Med 2005;352:2589-97.

20. Pearson FG, Goldberg M, Da Silva AJ. Tracheal stenosis complicating tracheostomy with cuffed tubes. Clinical experience and observation from a prospective study. Arch Surg 1968;97:380-94.

21. Pearson FG, Goldberg M, Da Silva AJ. A prospective study of tracheal injury complicating tracheostomy with a cuffed tube. Ann Otol 1968;77:867-81.

22. Goldberg M, Pearson FG. Pathogenesis of tracheal stenosis following tracheostomy with a cuffed tube. An experimental study on dogs. Thorax 1972;27:678-91.

23. Pearson FG, Cooper JD, Nelems JM, Van Nostrand AW. Primary tracheal anastomosis after resection of the cricoid cartilage with preservation of recurrent laryngeal nerves. J Thorac Cardiovasc Surg 1975;70:806-16.

24. Munro DD. Canada's first human lung transplantation: The untold story, with an update. Can J Surg 1994;37:432-7.

25. Nelems JM, Rebuck AS, Cooper JD, et al. Human lung transplantation. Chest 1980;78:569-73.

26. Cooper JD, Pearson FG, Patterson GA, et al. Technique of successful lung transplantation in humans. J Thorac Cardiovasc Surg 1987;93:173-81

27. Patterson GA, Cooper JD, Dark JH, Jones MT; the Toronto Lung Transplant Group. Experimental and clinical double lung transplantation. J Thorac Cardiovasc Surg 1988;95:70-4.

28. Keshavjee SH, Yamasaki F, Cardoso P, et al. A method for safe twelve-hour pulmonary preservation. J Thorac Cardiovasc Surg 1989;98:529-34.

29. Strueber M, Hoeper MM, Fisher S, et al. Bridge to thoracic organ transplantation in patients with pulmonary arterial hypertension using a pumpless lung assist device. Am J Transplant 2009;9:853-7.

30. Cypel M, Yeung JC, Liu M, et al. Normothermic ex-vivo lung preservation in clinical lung transplantation. $\mathrm{N}$ Engl J Med 2011;364:1431-40.

31. Delarue NC. Thoracic Surgery in Canada. A Story of People, Places, and Events. The Evolution of a Surgical Specialty. Toronto: BC Decker; 1989.

32. Walt AJ. The world's best-known surgeon. Surgery 1983;94:582-90.

33. Meakins J, Gallie WE, Graham EA. Obtituaries. Edward William Archibald. Can Med Assoc J 1956;54:194-8. 


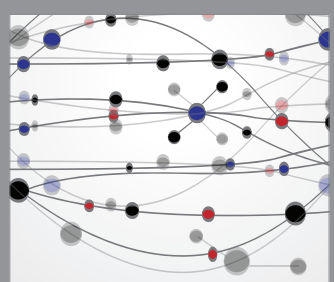

The Scientific World Journal
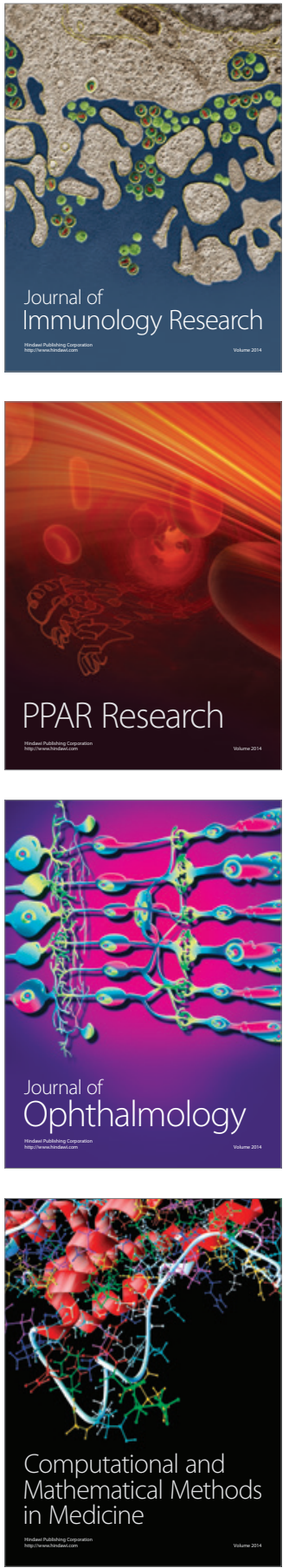

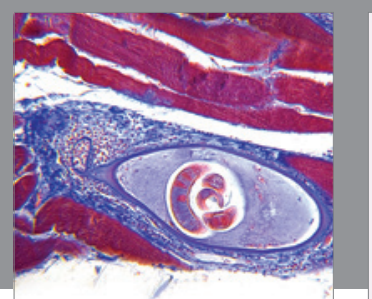

Gastroenterology Research and Practice

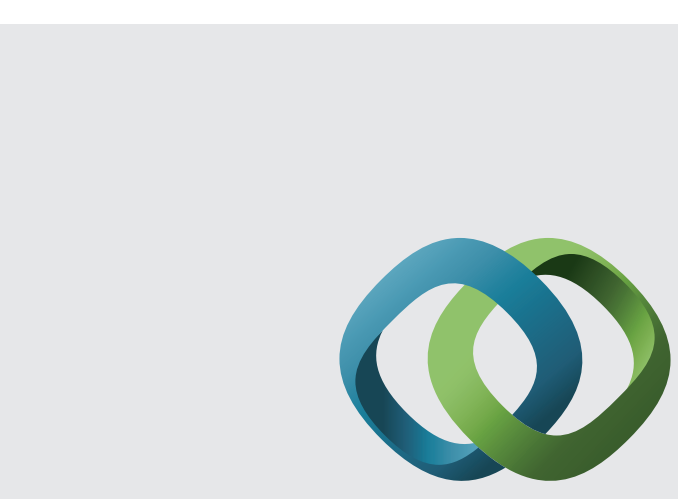

\section{Hindawi}

Submit your manuscripts at

http://www.hindawi.com
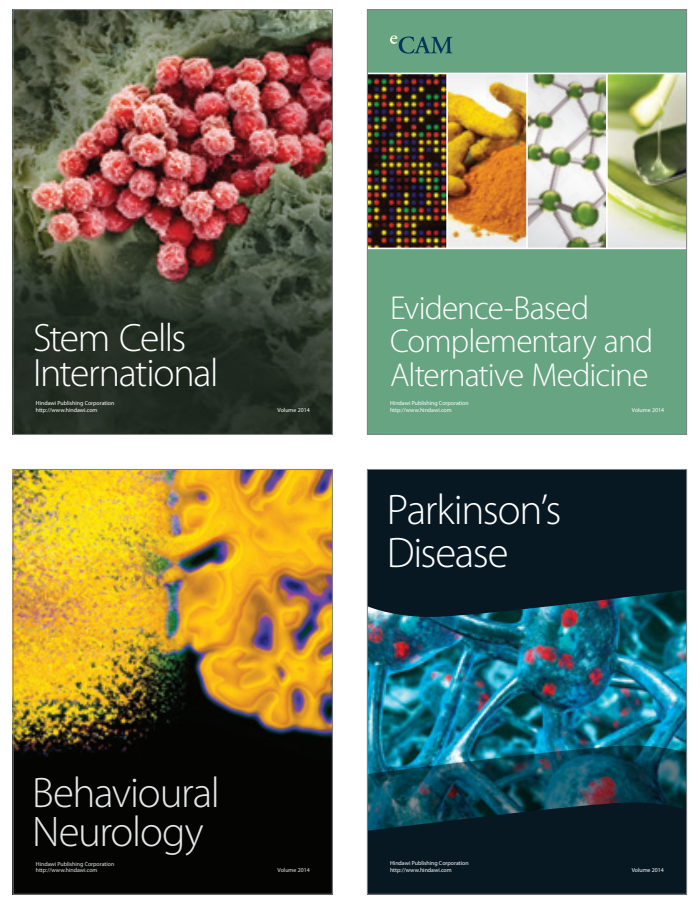
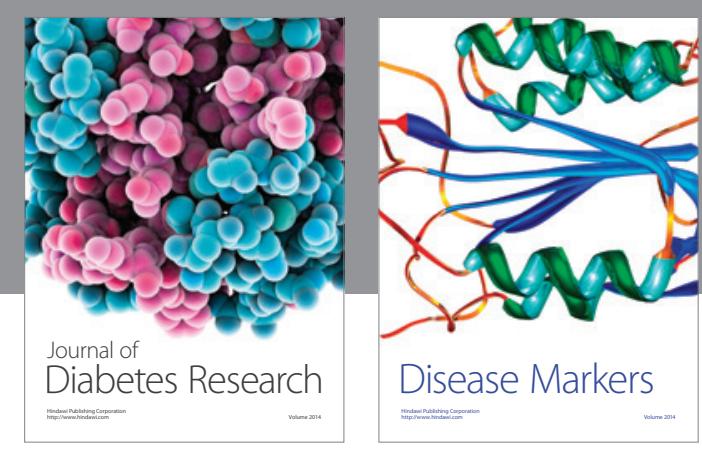

Disease Markers
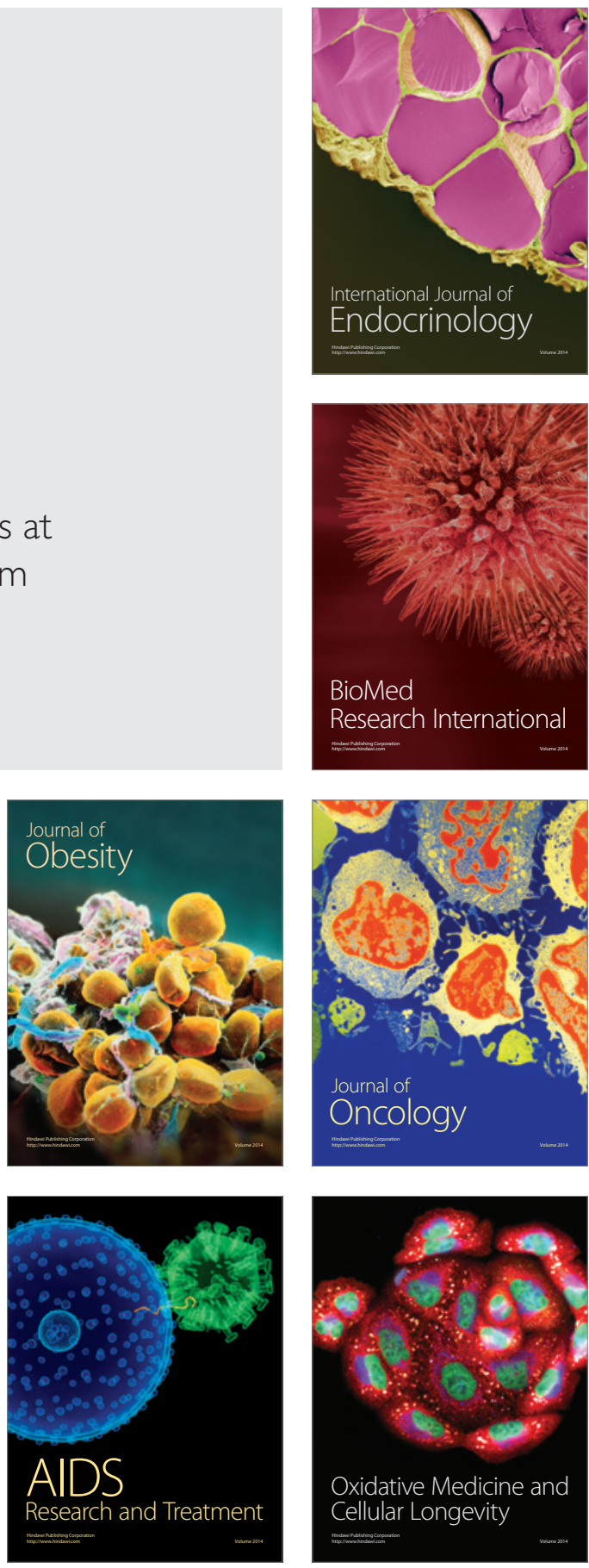